\title{
PRIME SAVINGS WITH PRIZES IN AN ISLAMIC PERSPECTIVE
}

\author{
Muhammad Wandisyah R. Hutagalung \\ Institut Agama Islam Negeri Padang Sidimpuan \\ Email: w@iain-padangsidimpuan.ac.id \\ Arbanur Rasyid, Fitri Yani Lubis \\ Institut Agama Islam Negeri Padang Sidimpuan \\ Email:rasyidabanur@gmail.com, fitriyanilubis@gmail.com \\ Andri Soemitra, Ismail Nura \\ Universitas Agama Islam Negeri Sumatera Utara \\ Email: atra@uinsu.ac.id, mailnura05@gmail.cpm
}

\begin{abstract}
PrimeSavings with Prizes is a savings that uses a mudharabah agreement. The problem in this research was that after the customer opens an account of prime savings with prizes, the customer will get a prize, even though the customer has not managed the savings by the bank. The provisions in syari'ah financial institutions, that the prize is a prize at the end of the period. This study aimed to determine how the implementation of Prime Savings at PT. Bank Muamalat, Padangsidimpuan branch office and to find out the concept of prime savings with prizes seen from an Islamic perspective. DSN Fatwa No.02/DSN-MUI/IV/2000 concerning savings, that the profit sharing must be stated in the form of a ratio and in the account opening contract. Second, DSN Fatwa No.86/DSN-MUI/XII/2012 concerning prizes in raising funds for syari'ah financial institutions. The research method used was a qualitative method with a descriptive approach. The types of data used were primary data sources and secondary data sources. Data processing techniques. The technique of collecting data were interviews, observation and documentation. Data analysis techniques were data reduction, data editing, data presentation, data conclusion and verification, and data validity techniques. This study found that the concept of giving gifts is a gift given by muamalat bank which is a gift at the beginning of the period, and the concept of gifts is based on interviews from ulama' and lecturers when viewed from an Islamic perspective that gifts are a voluntary gift from someone to another without expecting a reward so that it is allowed in muamalah without being wronged.
\end{abstract}

Keywords: Savings, Prizes, Islamic Perspective

\begin{abstract}
Abstrak
Ekonomi Islam merupakan ekonomi progresif dan dinamis. Berbagai teori-teori baru dimunculkan sebagai tawaran terhadap perkembangan ekonomi Islam, salah satunya yang dilakukan Abbas Mirakhor. Artikel ini membahas tentangdari prinsip utama sistem ekonomi sampai peran negara; sebuah tawaran Abbas Mirakhor terhadap ekonomi Islam. Dengan tujuan untuk mengetahui lebih mendalam pemikiran-pemikiran ekonomi Islam yang ditawarkan Abbas
\end{abstract}




\section{4 | Muhammad Wandisyah R. Hutagalung, et.al, PRIME SAVINGS WITH PRIZES IN AN ISLAMIC}

Mirakhor baik dari prinsip utama sistem ekonomi sampai peran negara dalam ekonomi. Artikel ini menggunakan jenis penelitian kualitatif yang menggunakan penelitian kepustakaan. Hasil penelitian ini memperlihatkan bahwa Abbas praktisi ekonomi dan keuangan Islam yang memiliki reputasi baik di dunia, baik Islam maupun Barat dan dianggap sebagai salah satu pembaharu dalam ekonomi Islam serta tergabung dalam madzhab Iqtishad. Dalam bidang sistem ekonomi Islam, Mirakhor berpendapat bahwa prinsip utama system ekonomi Islam menghendaki terjadinya pendistribusian dalam dua mekanisme, yakni kebebasan dan keadilan, tanpa itu tidak akan terwujud kesejahteraan. Oleh karenanya, perlunya pendekatan hermenuetik untuk menjawab berbagai permasalahan-permasalahan yang terjadi dalam sistem ekonomi Islam. Dalam kontek negara, menurut Mirakhor, negara memiliki peran yang sangat signifikan terhadap kesejahteraan masyarakat terutama lewat kebijakan-kebijakan produktif yang dikeluarkannya. Negara juga harus hadir dalam mewujudkan keadilan di tengah-tengah masyarakat.

Kata Kunci : Abbas Mirakhor, Sistem Ekonomi Islam, Peran Negara

\section{Introduction}

Bank Muamalat Indonesia (BMI) is the first commercial bank to operate in accordance with syari'ah principles. So that the review of business opportunities and operational strategies is not only studied from conventional bank business opportunities, but also needs to be studied from specific problems that are Islamic banking. In maintaining its existence, the bank will of course issue a variety of products according to market needs. What is meant by product is a group of tangible and intangible characteristics in which there are already color, price, packaging, prestige and service provided by producers that can be accepted by consumers as the satisfaction offered to consumer wants and needs. Products and facilities issued by the bank are a strategy to attract customers' attention to invest and place their funds in the bank, this is what PT Bank Muamalat Padangsidimpuan Branch Office has done through the Prime Savings with Prizes Products. In accordance with the benefits, the Prime Savings with Prizes is a time deposit with prize benefits according to the customer's choice (www.bankmuamalat.co.id accessed 09 january 2020, at 21: 34 Indonesian Western Time)

In both syari'ah and conventional banking institutions, the practice of giving prize is often found. If there is something that is easy to obtain, this is where the public's interest in obtaining something is easy or free by using various methods without 
considering the legal aspects. In Islam a gift can be interpreted as a gift from one person to another without any replacement with the intention of glorifying (Rasjid, 2017). One of the uslubs used by the Prophet SAW in cultivating gift giving is the order to give gifts. The following are the hadiths of the Prophet talking about gifts: The meaning : "Prophet SAW accepted the gift and returned it" (Muhammad, 2019).

Prizes originating from the bank itself are purely in the form of giving prizes to customers as a form of gratitude or appreciation for customer loyalty as the depositor of funds in the bank although the bank will provide requirements that must be met by customers as a sign of customer participation as prime savings customers with prizes. Prime Savings with Prizes uses the Mudharabah agreement, where the customer is the sahibul mall and the bank as the mudharib (Al-Hadi, 2017). The Mudharabah agreement has been known by Muslims since the time of the Prophet, and has even been practiced by the Arabs before the decline of Islam (Karim, 2013). Through the Mudharabah agreement, both parties will not receive interest, but instead will receive a share of the results of the economic project agreed upon in accordance with the provisions of the contract.

The Prime Savings with Prizes can be followed by individuals and nonindividuals in practice. The Prime Prize Program is not permanent but insindental only. The Prime Savings with Prizes Program was designed to attract customers to save their money at Bank Muamalat. The advantage of this product is that customers will not only get prizes, but customers will also get profit sharing each month (Private Interview with Rizki Fahlevi, Branch Manager, on 9 January 2019, at 09:54 Indonesian Western Time).

Based on the results of an interview with Mr. Rizki Fahlevi Asmara, the Prime Prize Savings mechanism is a way for customers to save money in prime savings with prizes with a certain target and period of time. Prizes given are in accordance with the agreed prize sizes according to the agreed year with a nominal ratio of savings which is directly proportional to the prize value (Pivate Interview witth Rizki Fahlevi Asmara, on 12 June 2020, at 19:15 Indonesian Western Time). In Prime Savings with Prizes, basically the profit sharing will be given in advance where the product will issue prizes 


\section{6 | Muhammad Wandisyah R. Hutagalung, et.al, PRIME SAVINGS WITH PRIZES IN AN ISLAMIC}

using a range according to the value of the savings with a non-standard calculation made by the division that issued the product, and a portion of the profit will be given every month, it's just that the profit sharing in the following months do not know exactly how much because the profit sharing cannot be predicted (Pivate Interview witth Rizki Fahlevi Asmara, on 12 June 2020, at 19:15 Indonesian Western Time).

In the Prime Savings with prizes, prizes can be taken or given to customers or authorized parties during the initial period of opening a prime savings account as a reinforcement of the commitment to place customer money at the bank for a specified period of time and the prize-taking mechanism is in accordance with the provisions applicable to Muamalat bank.

In the principle of fiqh, "Basically everything including mu'amalah can be done unless there are arguments that prohibit it" (Fatwa DSN No. No: 86/DSNMUI/XII/2012). The meaning of the above principle is that in every mu'amalah and transactions are basically permissible, such as buying and selling, leasing, pawning, cooperation, representation and others, except those that are forbidden, such as causing harm to gambling and usury.

As stated in the DSN fatwa No:02/DSN-MUI/IV/2000 regarding savings, the profit sharing itself may not be stated in any form but must be stated in the form of a ratio set forth in the savings account opening contract agreed by both parties. So, therefore, the customer's savings should be managed first, then the bank can provide benefits in the form of profit sharing to the customers themselves.

Prizes received by customers are not clear whether the prizes received by customers are the customers' rights taken from profit sharing or bank rights which are taken from profits every month and given to customers voluntarily. The problem that is examined in the writing of the Prime Savings with prize is that the customers' savings have not been managed by the bank but the profit sharing has been given by the bank first. In addition, according to the researchers, giving gifts like this could create risk opportunities for Islamic banks. There is a concern that after the customer gets the prize he wants, after a few days, the customer will withdraw the funds back. Meanwhile, Islamic banks have not had the opportunity to utilize the funds saved by customers. In 
addition, Islamic banks are prohibited from providing conditions for customers not to withdraw their funds as quickly as possible. Because prizes are free gifts without any specific conditions.

Therefore, the researchers are interested in researching and analyzing in depth the practices that are directly related to the Prime Savings with Prize. Based on the background, the researcher chose the title "Prime Savings with Prize in an Islamic Perspective (A Case Study at PT Bank Muamalat KC Padangsidimpuan)".

Based on the description on the background of the problem above, the researcher limited the problem in this paper. The limitation of the problem was the implementation of prime savings with prizes in an Islamic perspective (A case study at PT Bank Muamalat KC Padangsidimpuan) and the concept of prizes in prime savings with prizes from an Islamic perspective. Meanwhile, the researcher compiled the problem formulation by reviewing how the implementation of prima prima savings at PT Bank Muamalat Padangsidimpuan Branch Office and how the concept of prizes in prime savings with prize seen from an Islamic perspective at PT Bank Muamalat Padangsidimpuan Branch Office.

The objectives of this study were to determine how the implementation of the Prima Prize Savings at PT Bank Muamalat Padangsidimpuan Branch Office and to find out the concept of the Prime Savings with Prizes in an Islamic perspective. Theoretically, this study is expected to be useful for the development of scientific treasures, especially in the field of Islamic banking and finance.

\section{Savings}

Savings are public deposits in banks, which can be withdrawn at any time through a savings book or through an ATM machine (Darmawi, 2013). Savings are a form of liquid savings, this means that this product can be taken at any time if the customer needs it, but the profit sharing offered to small savings customers. However, the type of savings fund collection is a product of collecting which costs less for the bank because 


\section{Muhammad Wandisyah R. Hutagalung, et.al, PRIME SAVINGS WITH PRIZES IN AN ISLAMIC}

the profit sharing it offers is small, but the number of customers who use savings is usually more than other collection products.

Prime Savings with Prize is a savings program held by Bank Muamalat, a time deposit with prize benefits according to the customer's choice (www.bankmuamalat.co.id) Prime Savings with Prize is a type of time deposit that has a direct prize program, where prizes are deposited by BMI and will belong to the customer during the hold period (block) has been completed in accordance with the provisions of the program.

\section{Prizes Concept}

A prize is a contract of giving someone's property rights to someone else while he is still alive without expecting anything in return and remuneration, but in terms of habits, prizes are more motivated by someone's gratitude and admiration (Gusmita, 2017). Prizes can be interpreted as prizes from someone to others without any replacement with the intention of glorifying (Suhendi, 2008).

Prizes are prizes that are meant to glorify or feel love (Syafei, 2001). The virtue of giving gifts can be seen from the positive effect in the spirit of acceptance. Such as the loss of resentment and enmity and the emergence of affection between people. Fatwa of the National Syari'ah Council No:86/DSN-MUI/XII/2012 regarding prizes in raising funds for syari'ah financial institutions, namely:

First, fundraising is an activity of collecting public funds carried out by Syari'ah Financial Institutions which can be in the form of savings, time deposits and current accounts. Second, savings are deposits of public funds for the purpose of storing assets whose withdrawals can be made according to certain agreed conditions, which cannot be withdrawn using checks, bilyet giro, and other equivalent means. Third, a prize (hadiyah) is a gift that is non-binding and aims to make customers loyal to the LKS.

Third Party Funds Deposits (DPK) in Sharia Financial Institutions have provisions, namely LKS may give gifts or customer deposits, with conditions not agreed upon as the substance of the Fatwa of DSN-MUI Number:01/DSN-MUI/IV/2000 regarding Current Accounts, and Number: 02/DSN-MUI/IV/2000 concerning Savings. 
Not leading to the practice of hidden usury and / or not becoming the norm (habit, 'urf). If one of the parties does not fulfill its obligations or if there is a dispute between the parties, the settlement will be carried out through a syari'ah dispute settlement institution after an agreement is not reached through deliberation (https://tafsirq.com/fatwa/dsn-mui/hadiah-dalam-penghimpunana-keuangan-syari'ah, accessed on 24 July 2020, at 21:26 Indonesian Western Time).

According to Jumhur Ulama giving haram prize is requested to return under any circumstances, even if between siblings or husband and wife unless the prize giver is a father and the recipient is his own child, in the hadith Rasulullah SAW says which means "The person who withdraws his gift is like a dog that licks vomited." (Ghazaly, 2010). In contrast to the Hanafiyah ulama, according to them the gift itself is not binding. Therefore, the prize giver may revoke the prize, the reason they put forward is the hadith of the Prophet which means "People who donate their property are more entitled to their assets as long as the gift is not accompanied by compensation". However, they also prohibited withdrawing prizes from other people provided the grantee had given the reward and the grantee had received it (Ghazaly, 2010).

\section{Research Method}

This study was conducted at PT Bank Muamalat KC Padangsidimpuan which is in the area of Tapsel, Lecturers and Ulama. While the implementation was in December 2019-2020. The type of this study is qualitative research. The data collection technique was done by triangulation (combined), data analysis is inductive/qualitative and the results of qualitative research emphasize meaning rather than generalization (Sugiyono, 2018). This type of study is field study, namely study on "Prime Savings with Prizes in an Islamic Perspective (A Case Study at PT Bank Muamalat KC Padangsidimpuan)."

The subject in this study can be a place, or a place in the study. In data analysis, the number of units shows that there are many research subjects (Arikunto, 2013). Subjects in this study were places or respondents who were directly related to the problem to be studied, namely employees of Bank Muamalat KC Padangsidimpuan. In 


\section{0 | Muhammad Wandisyah R. Hutagalung, et.al, PRIME SAVINGS WITH PRIZES IN AN ISLAMIC}

this case, researchers collected data by contacting a prospective respondent who was considered representative. After that, go through the information obtained from these respondents can be contacted again by several selected respondents (Teguh, 2005).

The data sources in this study were primary data and secondary data. The primary data used was data obtained from field reviews at PT Bank Muamalat KC Padangsidimpuan to be the object of research through data and interviews with Bank Muamalat employees. Meanwhile, secondary data in this study were obtained from companies which can be seen in company documentation, reference books and other information related to the study.

Data collection techniques in this research used several techniques, namely Interview Techniques, Observation Techniques, and Documentation Techniques. Data processing is carried out in a descriptive qualitative form that seeks to describe and represent objects in accordance with what seeks to describe their existence and is often referred to as research that does not use numbers and analyzes using statistics (Sugiyono, 2009). Meanwhile, it took 3 interconnected processes to perform data analysis, namely Data Reduction, Data Editing, and Data Presentation. Then conclusions were obtained based on the process.

To ensure the validity of the data in this study, inspection and implementation techniques were needed. The implementation technique was based on a number of certain criteria. Triangulation is a data validity checking technique that utilizes something other than the data for checking purposes or as a comparison to the data (Moleong, 2002). Triangulation was carried out by comparing the observed data with the results of interviews, comparing what customers convey, and comparing the results of research with facts in the field.

\section{Results And Discussion}

Implementation of Prime Savings with Prizes at PT Bank Muamalat Padangsidimpuan Branch Office. In Fatwa DSN No.02/DSN-MUI/IV/2000 concerning Savings, it is explained that the justified savings are savings based on the mudharabah principle, namely a business cooperation agreement between two parties where the first 
party is a sharia bank as the owner of capital (shahibul maal) providing all (100\%) capital, while the another party is a financing customer who will be the manager (mudharib) of the business that will be run by both parties.

The agreement used in prime savings with prizes has met the general requirements based on the first mudharabah, in this transaction the customer acts as a shahibul maal or fund owner, and the bank acts as a mudarib or business manager, second, in its capacity as a mudarib, the bank can carry out various kinds of business not contradicting the principles of shari'ah and developing it, including mudharabah with other parties, third, capital must be stated in the amount, in cash and not receivables, fourth, profit sharing must be stated in the form of a ratio and set forth in the account opening contract, fifth, the bank as a mudharib covers the operational costs of the savings by using the profit ratio that is its right, sixth, the bank is not allowed to reduce the profit ratio of the customer without the consent concerned.

According to Mr. Rizki Fahlevi, from the results of the interview, the Prime Savings with Prizes product appeared in 2013, 2014 under the name Prime Savings with Prize (Private Interview with Rizki Fahlevi, on 07 September 2020, at 15.15 Indonesian Western Time). Interview with Ms. Hanifah that prime savings with prizes is a lot of enthusiasts, but in padangsidimpuan there is not much interest because it is seen from the balance, where the balance in the prime savings is a minimum of $\mathrm{Rp}$. $25,000,000$, and most customers prefer deposit savings because there is a profit sharing deposit every month and if the prime savings with prizes must be in accordance with the invested balance and cannot be withdrawn in accordance with the minimum agreement of 3 months (Private Interview with Hanifah, Customer Service, on 07 September 2020, at 15.50 Indonesian Western Time).

Prime Savings with Prizes is established to provide choices for customers, where the prima savings with prizes is made with a prize in front of the prize which is assumed, the calculation is the lowest profit sharing. From an interview with Rizki Fahlevi that the system used in prized prima savings is a holding system, the holding is kept or blocked, only when the prize period is due. The savings remain active even 


\section{2 | Muhammad Wandisyah R. Hutagalung, et.al, PRIME SAVINGS WITH PRIZES IN AN ISLAMIC}

though the prize period has ended. For example, the 5 year prize and in the 6th year the prima savings are still active, and if the system is due in the month of maturity, the system will be blocked automatically without having to come by the customer to release it, the prize has been obtained and the money kept is automatically released.

The mechanism for giving prizes in prime savings with prizes is 14 working days from the incoming funds and approval, the savings are opened and a letter of approval is made from the customer, then the customer chooses what prizes to declare, starting with how many prizes then determining the prize, and will be submitted to Jakarta and customers can also go home on the D day, the prize will be waited for up to 14 working days, the maximum prize is given at the beginning of the period. The profit sharing calculation mechanism at the bank follows the special name of the ratio that applies to $\mathrm{TPB}$, a special calculation is given that is why customers can get the same prize as TDTD (Time Deposit Deposit), deposits also get a special ratio for above average Rp. 100.000.000 if the deposit is below Rp. 100.000.000 customers cannot receive such a special ratio with prime savings with prizes. So the portion for the results is higher than the ratio obtained at the customer service counter (Private Interview with Rizki Fahlevi, on 07 September 2020, at 15.15 Indonesian Western Time).

In the contract, there is a difference in the profit sharing that will be disclosed in the following months, until the end of that month it has been accumulated to be the prize, the rest will go to the account The rest is a little bit so this prize is actually the entire revenue share for almost the entire profit sharing that will be obtained for 60 months, this revenue share will be put into the prize itself.

Prizes that take precedence are indeed prizes because the profit sharing that runs every month, therefore the minimum profit sharing that ever counts is used. Sometimes there is a profit sharing of 350 and 400 but the profit sharing used is 350 a month for Rp. 100,000,000 is not using 400 for one month, because if you use a higher value then the customer is the one who is lucky and the bank will lose out. The prize given to the customer is the customer's own right which is taken from the savings profit sharing but in reality it seems as if the prize is a prize from the bank. 
The period for depositing funds starts from 3 months-60 months. prizes can be selected according to customer wishes with a customer ratio of 5\%:Bank 95\% with active monthly service fee:Rp. 11,000 and passive:Rp. 15,000, Regular monthly card fee (GPN):Rp. 2,500, Classic: Rp. 2,500, 1HRAM/priority:Rp. 5000, card replacement fee of Rp.20,000. Prizes such as precious metals, cellphones, cars, TV, washing machines, motorbikes (Private Interview with Rizki Fahlevi, Branch Manager, on 09 Oktober 2020, at 17.59 Indonesian Western Time).

Opening the prime savings with prizes account, customers come directly to the bank office with their ID cards and savings book, after which the customer service will open their accounts with the prime savings with prizes code, and on the day of opening the customers' funds will be held and processed for 14 working days to collect prizes given to customers. Prime savings with prizes are never closed even though the 5 years period has expired if the customer does not ask to be closed. Savings are the right of the customers, ATM savings can still be used, but prime savings with prizes will return to normal savings with no more hold on balance, however if the customer asks for prime savings with prizes to be closed, the prime savings closing fee is Rp. 50.000 (Private Interview with Hanifah, Customer Service, on 07 September 2020, at 15.50 Indonesian Western Time).

Customers cannot exchange prizes for cash. If the prize is not available, Bank Muamalat can replace it with another equivalent prize, the kind of the prize depends on the supply and the prize itself is included in tax, the list of prizes can change at any time according to Bank Muamalat's provisions. Customers who close the prime savings with prizes account before agreed day will be charged a prize replacement fee (Brosur Hijrah itu Berkah pada Tabungan Hijrah Prima Berhadiah)

The responses of the customers to the prime savings with prizes is good, because many customers wonder, even though not all of them are closed, but customers still hope that because the customers' money is insufficient, but the customers' responses to the products are good. 


\section{4 | Muhammad Wandisyah R. Hutagalung, et.al, PRIME SAVINGS WITH PRIZES IN AN ISLAMIC}

The obstacle in prime savings with prizes is that sometimes the prizes have to be from Jakarta, even though they already exist in Padangsidimpuan. Jakarta is indeed easier, but the shipping costs need to be taken into account, sometimes the bank asks for relief to Jakarta to collect the prize at Padangsidimpuan because the customer chooses the prize at another shop. The obstacle is that the prizes that the customer wants are in other stores, while the Jakarta version of the prize flyers is all that is why the bank asks for the diversion of the prizes to be selected by the customer and the customer appointed to which store (Private Interview with Rizki Fahlevi, on 07 September 2020, at 15.40 Indonesian Western Time).

\section{The Concept of Prizes in the Prime Savings with Prizes Viewed from an Islamic Perspective at PT Bank Muamalat Padangsidimpuan Branch Office}

The concept of prizes at Bank Muamalat Padangsidimpuan Branch Office is that the prizes given by syari'ah financial institutions are prizes at the end of the period, but at Muamalat bank the prizes will be given at the beginning as a borrowed prizes and will be used free of charge by the customers. If the customer suddenly asks for his savings, the prize value will be calculated proportionally.

According to Mr. Amsir Saleh, from the results of the interview, the prizes are divided into two types, the prizes are the results collected from the results of the competition participants, for example when registering for the race, all members of the competition pay registration fees, the results of the list money collected will be made into prizes, then it is called gambling which is haram because what is contested is the capital of the competitions.

In Islamic banking there are prizes but prizes are given from the results of the customer, for example, deducting the percentage of the customers' own profit, if that is what the bank makes a prize, it is the same as gambling, because the prize that is prepared is taken from the customer and the prize will be given to the winning customer among customer, it is haram in any form as long as the prize comes from the money of the customer or participant. But if the prize is prepared by an institution, by the government such as musyabaqah tilatul Qur'an, the people who take part in the meeting 
will not be charged any fees, and the prizes provided by the government are in the form of gifts that are lawful, because they do not contain elements of gambling )Private Interview with Ustad Amsir Saleh, on 15 September 2020, at14.20 Indonesian Western Time).

Samar is tied to the haram, because the Messenger of Allah said that it is clear that it is halal, the haram is clear, some of which are vague, but the Prophet said who fell on the unclean those who had fallen to the haram. Samar is in essence closer to the law to the haram. In conclusion, prizes that have nothing to do with participants or customers, and are prepared by an institution or government, are lawful (Private Interview with Ustad Amsir Saleh, on 15 September 2020, at14.20 Indonesian Western Time).

There are many forms of prizes, for example prizes in fishing competitions, where participants in fishing competitions will pay competition money and the prizes are prepared from the competition list money, so that is referred to as gambling. Prizes that are essentially taken from the customers' profit, and deducted by interest, then the prizes are the result of the customers themselves, not from the intention of the bank, is called gambling which is haram.

Savings in the view of Islam itself is allowed, it is different from the problem of saving, it is also a matter of prizes. If saving is just saving, the problem is that saving is in the form of interest or in the form of profit sharing, if saving in the form of interest is clearly an automatic increase, because it is a direct increase in the percentage of capital, but if the increase is from profit sharing, the increase does not automatically depend on profits earned by the bank.

If the profits are high, the savings customers will get high profits and if the bank profits are low, the savings customers will get low profits. If the savings system is syari'ah then it is lawful, but if the savings system is conventional it has been denied by the scholars that it is haram (Private Interview with Ustad Amsir Saleh, on 15 September 2020, at14.20 Indonesian Western Time). 


\section{6 | Muhammad Wandisyah R. Hutagalung, et.al, PRIME SAVINGS WITH PRIZES IN AN ISLAMIC}

The concept of prizes is basically allowed, but do not take the form of gambling and if it does not have an element of gambling then the prize is lawful, because prizes are prizes, there are alms, there are grants, there are waqf. The prize is a form of giving if in the fiqh book the prize is given to someone who is able, and the prize has been repaid. If we were rewarded with something then we have already repaid it, so prizes have different meanings.

A prize in a fiqh book means a form of prize, for example we go to a party, we will give an envelope, then that means a gift to the partying person. This reward means that circumcision is repaid if we are given a gift, one day we will get circumcision repaid. There are also prizes called giving for the success of the race, the winner will be given a prize but this prize is not included in the category of circumcision as a reward because this prize includes giving for his success. So it is not the same as the prize referred to in the fiqh book, if a prize like this may be the condition as long as the prize does not come from the competition participants.

According to Mr. Fatahuddin Siregar, from the results of the interview, the gift is a voluntary gift from someone to another without expecting anything in return, so a gift has a legal basis, which means giving gifts to you and then you will love each other. That giving gifts is not prohibited because it is something that is clearly legal (Private Interview with Fatahuddin Aziz Siregar, Dosen IAIN Padangsidimpuan, on 21 September 2020, at 14:04 Indonesian Western Time).

There are some ulama who equate gifts with grants, grants are the same as voluntary giving, but if a gift has an aspect of appreciation, a gift without anything has been given a gift. That reward if someone has an achievement will definitely be given a reward, so there are even orders that allow it. But the command itself is not obligatory but rather an order in the form of circumcision, even when there is no argument against it in muamalah as long as it is not prohibited.

In terms of muamalah it is basically allowed as long as there are no restrictions, it even has suggestions, so there is no problem. The prize itself is permissible, something that is permissible. In the prime savings account itself has a promotional effect, prizes in prime savings with prizes are not suitable, because the prizes are actually given to 
customers free of charge and the profit sharing is their own right. If what is called a prize is not the right of the customer, the prize can be given to the customer, the profit sharing form is a voluntary prize without expecting a reward if that is the customer's right. For example, I gave a gift to Fitri, then the gift would belong to her. The actual prize made by the Bank is more a promotion that aims at promotion (Private Interview with Fatahuddin Aziz Siregar, Dosen IAIN Padangsidimpuan, on 21 September 2020, at 14:04 Indonesian Western Time).

Savings in the view of Islam are something that is permissible. There is nothing wrong with saving money. The concept of the prize itself is a voluntary giving of someone to another without expecting anything in return, the prize has an element of appreciation.

According to Mr.Muhammad Arsad, from the results of the interview that a prize in Islam is permissible or is meant by mubah, and mubah is something that can be done to reward one's achievements. The law of the prize is jais or mubah, which is allowed to have a neutral legal meaning, is above almsgiving. Almsgiving is done and praised because it is tied to the poor, but if it is a prize it means that it is permissible. If the goal is to motivate then it becomes reward and goes up to sunnah or zakat whose intention is to motivate to perform worship, to get closer to Allah SWT then it will rise to the sunnah (Private Interview with Muhammad Arsad, Lecturer at IAIN Padangsidimpuan, on 10 Oktober 2020, at 09:46 Indonesian Western Time).

Mr. Muhammad Arsad said that prizes in the prime savings with prizes account itself are not included in the prize category, because what is said is prizes given to others for their achievements. For example, there is a Simpedes prize, there is a motorbike prize, which will use a prize revocation system from savers, so the number that is withdrawn is one of the bank's customer numbers, of course the customer whose number is revoked has requirements in the amount of savings.

A prize like that is what is meant by a prize, so the prime savings with prizes itself is not appropriate because it is just a trick by the bank, and that there has never been a contract like that in Islamic economics. There cannot be two contracts in a 


\section{Muhammad Wandisyah R. Hutagalung, et.al, PRIME SAVINGS WITH PRIZES IN AN ISLAMIC}

transaction, because later it will cause confusion, one side is said to be a prize and on the other hand it is said to be buying and selling installments.

Prizes are achievements from someone, then other will be rewarded for their achievements without strings attached. For example, a customer saves in a bank for two years, because the savings customer himself is honest and routine in saving, the bank gives a prize, and it can also be said that customers who use a murabahah contract, buy and sell cars, buy and sell land then the saver pays monthly installments, and installments. what the customer does is always fixed every month and is never in arrears in payments, therefore because the customer is good at making installments, the customer will be given a gift by the bank (Private Interview with Muhammad Arsad, Lecturer at IAIN Padangsidimpuan, on 10 Oktober 2020, at 09:46 Indonesian Western Time).

The prizes given to the customers themselves are included in the category of achievement, where the achievement is that the customer is a good borrower, so it is very natural for the bank to give a prize, and that is what is meant by the meaning of a contract in the shari'ah economy where the prize is given on the basis one's accomplishments.

\section{Analysis of Discussion Results}

The results obtained in this study are in the implementation of the Prime Savings with Prizes at PT Bank Muamalat Padangsidimpuan Branch Office, customers directly come to the bank office with their ID cards and savings book, then customer service will open their accounts with the Prime Savings with prizes code, and make a statement of approval from the customers, after that the customers will choose what the prize is and what the prize value is. On the day of opening a savings account, the customer's funds will be held and processed for 14 working days to collect prizes given to customers.

The concept of prizes in the Prime Savings with Prizes from an Islamic perspective at PT Bank Muamalat Padangsidimpuan branch office is that Bank Muamalat gives gifts to customers at the beginning of the period as gifts that are borrowed and will be used free of charge by customers. A prize viewed from an Islamic 
perspective is a voluntary prize from someone to another without expecting anything in return, then the prize has a legal basis, which means giving prize to each other then they will love each other. So that the authors conclude giving prizes to savings products is allowed as long as no party is wronged.

In addition, giving prizes that are applied to Savings products at Bank Muamalat will provide benefits to both parties. Muamalat Bank as a financial institution that collects funds from the public, will easily carry out its function as an investment manager, because it has succeeded in raising funds from the public. As a customer, of course the public will get a sense of security and comfort when investing in Islamic banks. In addition, in addition to obtaining profit sharing, customers will also receive prizes as offered by the Prime Savings with Prizes products by Muamalat Bank. In this case, it requires transparency from the Islamic bank. Islamic banks should mention that the prize received by the customer is something that is taken from the profit that the customer will get. So, the researchers conclude, if there is no prize, the customer will also get a profit as big as the prize obtained at the beginning. Hence in this case the need for transparency from Islamic banks. In addition, giving prizes at the beginning of the contract is something that needs to be reviewed again. Because the prizes given come from the profit sharing that will be given to customers. So, in this case, the reward and profit sharing is something that is not different. It is just that it is given a different naming. According to the researchers, giving prizes with a concept like this should be improved. Because if it refers to the context of the Prime Savings with Prizes, prizes and profit sharing are the same things. Profit sharing should be obtained by the customer, after the funds he has saved are managed by the Islamic bank, and earned a profit, the Islamic bank will be obliged to provide profit sharing every month, not at the beginning of the contract when the customer saves, especially by giving a different naming as a prize.

\section{Conclusion}

In the Bank Muamalat, The Prime Savings with Prizes product appeared in 2013, 2014 under the name Prime Savings with Prize. Prime savings with prizes is a lot of 


\section{Muhammad Wandisyah R. Hutagalung, et.al, PRIME SAVINGS WITH PRIZES IN AN ISLAMIC}

enthusiasts, but in padangsidimpuan there is not much interest because it is seen from the balance, where the balance in the prime savings is a minimum of Rp. 25,000,000, and most customers prefer deposit savings because there is a profit sharing deposit every month and if the prime savings with prizes must be in accordance with the invested balance and cannot be withdrawn in accordance with the minimum agreement of 3 months.

Prime Savings with Prizes is established to provide choices for customers, where the prima savings with prizes is made with a prize in front of the prize which is assumed, the calculation is the lowest profit sharing. From an interview with Rizki Fahlevi that the system used in prized prima savings is a holding system, the holding is kept or blocked, only when the prize period is due. The savings remain active even though the prize period has ended. For example, the 5 year prize and in the 6 th year the prima savings are still active, and if the system is due in the month of maturity, the system will be blocked automatically without having to come by the customer to release it, the prize has been obtained and the money kept is automatically released.

The mechanism for giving prizes in prime savings with prizes is 14 working days from the incoming funds and approval, the savings are opened and a letter of approval is made from the customer, then the customer chooses what prizes to declare, starting with how many prizes then determining the prize, and will be submitted to Jakarta and customers can also go home on the D day, the prize will be waited for up to 14 working days, the maximum prize is given at the beginning of the period.

The concept of prizes at Bank Muamalat Padangsidimpuan Branch Office is that the prizes given by syari'ah financial institutions are prizes at the end of the period, but at Muamalat bank the prizes will be given at the beginning as a borrowed prizes and will be used free of charge by the customers. If the customer suddenly asks for his savings, the prize value will be calculated proportionally. The prizes are divided into two types, the prizes are the results collected from the results of the competition participants, for example when registering for the race, all members of the competition pay registration fees, the results of the list money collected will be made into prizes, 
then it is called gambling which is haram because what is contested is the capital of the competitions.

In addition, giving prizes that are applied to Savings products at Bank Muamalat will provide benefits to both parties. Muamalat Bank as a financial institution that collects funds from the public, will easily carry out its function as an investment manager, because it has succeeded in raising funds from the public. As a customer, of course the public will get a sense of security and comfort when investing in Islamic banks. In addition, in addition to obtaining profit sharing, customers will also receive prizes as offered by the Prime Savings with Prizes products by Muamalat Bank. In this case, it requires transparency from the Islamic bank. Islamic banks should mention that the prize received by the customer is something that is taken from the profit that the customer will get. So, the researchers conclude, if there is no prize, the customer will also get a profit as big as the prize obtained at the beginning. Hence in this case the need for transparency from Islamic banks. In addition, giving prizes at the beginning of the contract is something that needs to be reviewed again. Because the prizes given come from the profit sharing that will be given to customers. So, in this case, the reward and profit sharing is something that is not different. It is just that it is given a different naming. According to the researchers, giving prizes with a concept like this should be improved. Because if it refers to the context of the Prime Savings with Prizes, prizes and profit sharing are the same things. Profit sharing should be obtained by the customer, after the funds he has saved are managed by the Islamic bank, and earned a profit, the Islamic bank will be obliged to provide profit sharing every month, not at the beginning of the contract when the customer saves, especially by giving a different naming as a prize. 


\section{REFERENCES}

Al Hadi, Abu Azam, (2017). Fiqih Muamalah Kontemporer, Depok: Rajawali Pers.

Arikunto, Suharsimi, (2013). Manajemen Penelitian Ekonomi, Jakarta: PT. Rineka Cipta.

Ascarya, (2013). Akad dan Produk Bank Syari'ah, Jakarta: Rajawali Pers.

Darmawi, Herman, (2012). Manajemen Perbankan, Jakarta: Bumi Aksara.

Ghazaly, Abdul Rahman, dkk, (2010). Fiqih Muamalat, Jakarta: Prenadamedia Group.

Imrah, Musthafa Muhammad, (2002). Jawahir Al-Bukhari, Jakarta: Pustaka Al-Kautsar.

Karim, Adiwarman A. (2013). Bank Islam Analisis Fiqih dan Keuangan, Jakarta: PT Raja GrafindoPersada.

Karim, Helmi, (2002). Fiqih Muamalah, Jakarta: PT. Raja Grafindo Persada.

Kasmir, (2010). Dasar Perbankan, Jakarta: PT. Raja GrafindoPersada, 2010.

Lubis, Suhrawardi K., Farid Wajid, (2012). Hukum Ekonomi Islam, Jakarta: Sinar Grafika, 2012.

Moleong, Lexi J, (2002). Metode Penelitian Kualitatif, Bandung: PT. Remaja Rosda Karya.

Muhammad, (2008). Metode Penelitian Ekonomi Islam: Pendekatan Kualitatif, Jakarta: Raja Wali Pers, 2008.

Mulyana, Deddy, (2007). Metode Penelitian Kualitatif, Bandung: PT. RosdaKarya.

Rajid, Sulaiman, (2002). Haji, Fiqih Islam, Bandung: Sinar Baru Algensindo, Cet 80.

Shihab, M. Quraish, (2002). Tafsir Al-Mishbah, Vol. 6, Jakarta: Lentera Hati.

Shihab, M. Quraish, (2003). Tafsir Al-Mishbah, Vol. 14, Jakarta: Lentera Hati.

Suhendi, Hendi, (2008). Fiqih Muamalah, Jakarta: PT. Raja Grafindo Persada.

Suwiknyo, Dwi, 2010. Ayat-ayat Ekonomi Islam, Yogyakarta: Pustaka Pelajar.

Syafei, Rachmad, (2001). FiqihMuamalah, Bandung: CV. Pustaka Setia.

Teguh, Muhammad, (2005). Metodologi Penelitian Ekonomi, Jakarta: PT. Raja Grafindo Persada, 2005. 